\title{
A BUSINESS FRAMEWORK TO NETWORK SMALL SOUTH AFRICAN ENTERPRISES FOR SUSTAINABILITY
}

\author{
R.P. Brand ${ }^{1}$, N.D. du Preez ${ }^{2}$ and C. Schutte ${ }^{3}$ \\ Department of Industrial Engineering \\ University of Stellenbosch, South Africa \\ 1riaan@indutech.co.za, ${ }^{2}$ nddp@sun.ac.za, ${ }^{3}$ corne@sun.ac.za
}

\begin{abstract}
This paper describes the role and use of enterprise engineering concepts as a formal approach to the deployment of sustainable networks of small businesses in South Africa. Small, medium and micro enterprises (SMMEs) operating in the informal South African economy struggle to survive for various reasons. A business framework is suggested that supports informal SMMEs through their initial stages of operation, and by doing so, improves sustainable growth and employment opportunities. This implies integration of informal business activities with the formal economy. The business framework is constructed using the Zachman Enterprise Reference Architecture, and is benchmarked by a small-scale fish farming project case study to validate the research hypothesis.
\end{abstract}

\section{OPSOMMING}

Hierdie artikel beskryf die toepassing van bedryfsingenieurswesebeginsels as 'n formele benadering tot die ontwikkeling van volhoubare netwerke van klein ondernemings in Suid-Afrika. Verskeie faktore dra by tot die sukkelende voortbestaan van "SMMEs" in die informele ekonomie van die land. As moontlike oplossing vir hierdie probleem word ' $\mathrm{n}$ besigheidsraamwerk voorgestel wat informele "SMMEs" gedurende hul aanvangsfase ondersteun en daardeur volhoubare groei en werkskeppingsgeleenthede verbeter. Realisering van hierdie besigheidsraamwerk impliseer integrasie-aktiwiteite tussen die informele en formele ekonomieë. Die besigheidsraamwerk is ontwikkel met behulp van Zachman se Besigheidsverwysingsargitektuur. 'n Visboerderyprojek dien as gevallestudie vir validasie van hierdie navorsingshipotese.

\footnotetext{
${ }^{1}$ The author was enrolled for the degree of MSc in Engineering at the Department of Industrial Engineering, University of Stellenbosch.
} 


\section{INTRODUCTION}

South Africa's recent political history, and particularly its international isolation until the 1990s, is one of the main reasons for the country's economic inequities. This phenomenon challenges the present government to implement innovative solutions that promote business development and create employment opportunities. Since the 1994 elections, there has been a growing awareness of the importance of entrepreneurship and the implementation of the necessary support mechanisms required to sustain new businesses. Small, medium and micro enterprises (SMMEs) play a significant role in employment creation and are one of the main drivers of economic growth. Balkenhol et al [1] argue that the high rate of unemployment in South Africa affects the number of informal SMMEs, as people are forced to make a living. Starting a successful new business venture requires both human and environmental resources (Baum et al [2]). Recent research recommends that government policies and development programmes be directed towards increasing awareness of entrepreneurial career possibilities, as well as providing the opportunity to gain entrepreneurial experience (Rotefoss et al [19] and Drennan et al [7]).

In South Africa, enterprise development remains an important area of cooperation across all areas of government. In order to create suitable work for entrants into the labour market, it is necessary that new enterprises are created and that existing enterprises become more competitive (Burger [5]). Various programmes to improve the delivery of essential social services to the majority of the population are underway. These focus on the delivery of better opportunities in education and business. Unfortunately, they are not sufficient to address the country's enormous need for employment opportunities in a timely fashion (Rogerson [18]).

This paper highlights the factors that influence the sustainability of informal SMMEs, and suggests a method that can be used to transform them into more formal businesses that are integrated into the formal economy. A business framework is proposed - a concept that acts as a bridge between informal enterprises and the formal economy. In practice this business framework will be realised by the registration of a legal business entity to which similar SMMEs can be affiliated. Business solutions provided by such a business entity include financial services, customer and supplier management, logistic services, project planning, and business training. This business entity should not be too complex and must be easy to understand and implement; on the other hand, it must not be too simplistic. Role players in this business framework are informal SMMEs, formal enterprises, investors, and the government.

\section{LITERATURE REVIEW AND HYPOTHESIS DEVELOPMENT}

Although the current economic and political environment in South Africa is favourable towards entrepreneurs who operate their own businesses, most SMMEs in the informal economy find it difficult to survive or contribute formally to economic activities. A major concern is the availability of resources (e.g. finances, training, management skills, and general services) to support these SMMEs (Balkenhol et al 
[1] and Lehohla [11], [12]). While the economy is in a process of transition, with business becoming more integrated into the international system, the local government still has to address economic disparities between population groups, stimulate growth, and create work opportunities. An understanding of the factors that influence the sustainability of informal SMMEs is necessary if the government is to develop policies and programmes that encourage entrepreneurship and improve business development (Drennan et al [7]). South Africa's more than 2-million small businesses represent $98 \%$ of the country's total number of firms, employing 55\% of the labour force and contributing $42 \%$ of the country's wage bill. Yet $87 \%$ of these enterprises are survivalist and operate outside the formal economy (Le Roux [13]).

\section{Conceptual issues and definitions}

Definitions for small enterprises differ from country to country and also between institutions within countries. The term 'SMME' is mostly South African-related and includes 'micro' enterprises, as opposed to the more general accepted term 'SME'. The South African Small Business Act of 1996 [20] defines SMMEs based on the number of employees per enterprise size category in combination with the annual turnover for the specific sector in which the enterprise operates. This article focuses on informal SMMEs that have five employees or fewer, and a turnover of less than R300,000.

Eapen [8] adds to this:

Some analysts define 'informal' activities in terms of the absence of characteristics that belongs to 'formal' activities like security of work, better earnings, existence of non-wage and long-term benefits, protective legislation and union protection.

The International Labour Organisation [10] recommended at the 2002 International Conference for Labour Statistics (ICLS) that the informal sector be defined in terms of one or more of the following criteria (see also Devey et al [6]):

- Non-registration of the enterprise in terms of national legislation such as taxation or other commercial legislation.

- Non-registration of employees of the enterprise in terms of labour legislation.

- Small size of the enterprise in terms of the number of people employed.

- Small annual turnover.

Impediments to business development

Balkenhol et al [1] argue that a common constraint on business development in South Africa is the high failure rate of start-up SMMEs. It is reasonable to argue that survival of SMMEs in both the formal and informal economy is a major concern. Many business owners and employees in the informal economy are less skilled than their counterparts in the formal economy, placing these informal SMMEs in a high risk category (Burger [5]). The most prominent impediments to business development (and survival) are explained as follows: 
- Access to finance. Finances are critically important, especially for firms that show entrepreneurial talent and skills to grow (Berry et al [3]). Financiers are unwilling to enter the informal SMME segment of the market owing to the high risks associated with these businesses (Balkenhol et al [1]). Sixty percent of nonVAT-registered business owners required additional money to start their businesses, but only 5.1\% of these informal SMMEs managed to obtain loans from commercial banks (Lehohla [11], [12]). South African SMMEs use their own funds as start-up capital (Balkenhol et al [1]). In an attempt to facilitate access to loan finance to SMMEs, the South African government established Khula Finance Ltd as a 'wholesale' institution to support financial intermediaries. It is believed, however, that this policy initiative has not lived up to expectations (Berry et al [3]).

- Lack of business skills. Exposure to management experience further impacts on the management skills of entrepreneurs (Balkenhol et al [1]). Years of restrictions and control of access to entrepreneurial opportunities created a mindset focused on wage and salaried work rather than the establishment of small businesses and entrepreneurs (Balkenhol et al [1]). This process has led to an increasing number of people who become economically active but cannot find employment and do not have the capacity to embark on self-employment or other income-generating activities (Lehohla [11], [12]).

- General services. It is reasonable to argue that being able to run a formal business assumes the presence of important infrastructural elements. Many of these SMMEs do not have access to general services such as business premises, electricity, telephone, water, or sanitation (Lehohla [11], [12]).

- Influence of immediate communities. Operating a business in a poor community is extremely difficult, as potential customers are also struggling to make a living and have little money to spend (Devey et al [6]).

- Isolated operation. Without a permanent address or telephone it is extremely difficult for these businesses to communicate efficiently. The lack of access to communication technologies hampers the exchange of ideas, the integration of services, and the ability to tender or to conclude contracts. This leads to many business processes being excluded (isolated) from business opportunities.

- Business registration. Only 7.3\% of non-VAT registered businesses obtained a licence or permit to operate their business (Lehohla [11], [12]). Business owners do not register their businesses because of the lack of general services.

- Ineffective business processes. Without processes like supply, marketing, and distribution that enable customer or supplier interaction, these informal SMMEs cannot benefit from the stream of resources (or money) that is in circulation.

- Competition and the nature of the economy. In South Africa most sectors are concentrated around a few large firms. Both formal and informal SMMEs 
therefore find it difficult to enter highly competitive markets to compete against these larger established firms (Balkenhol et al [1]).

The performance of the formal economy has an effect on the number of informal SMMEs and on their sustainability. Pressure in the formal economy (e.g. slow growth, high inflation, legislation, or low foreign investment) can lead to an increase in unemployment figures, which in turn increases the number of survivalist SMMEs (Balkenhol et al [1]). 'Survivalist' refers to that category of SMMEs whose owners started a business because they could not keep or acquire employment in the wage economy. Most survivalist SMMEs are disbanded or closed when the owner finds employment (Balkenhol et al [1]). SMME growth and prosperity are clearly not 'stand-alone' aims to be pursued in ignorance of the broader economic policy. In fact, it is easy to understand that SMME growth can be strongly affected by the macroeconomic context (Berry et al [3]).

Various governmental support policies and programmes have been implemented, but many of these initiatives have not lived up to expectations (Budlender et al [4] and Devey et al [6]). Another facility for sustainable business development is needed. This again launches the quest to find a sustainable solution that would support SMMEs and entrepreneurs with business structures that eliminate early risks and enable them to participate in the formal economy. The suggested business framework is aimed at fulfilling this role by integrating informal SMMEs with formal economic activities. The objective would be to create a legal business entity (based on the concept of the business framework) to which entrepreneurs and informal SMMEs are affiliated. This agreement allows them to operate a business under favourable conditions until the business is mature enough to function on its own.

\section{Hypothesis}

SMMEs in the second (informal) economy find it difficult to participate in formal economic activities. This raises questions about the ability of these enterprises to contribute to the formal economy in a sustainable manner. Ideally, one would like to use these SMMEs as a vehicle that provides inexperienced business owners with the opportunity of capitalising on the country's competitive and comparative advantages.

Developing a business framework that supports and grows networks of SMMEs may provide an answer to the abovementioned problem. This proposed solution has led to the following research hypothesis:

SMMEs in the second economy struggle to survive, but when affiliated to a legal business entity (based on the concept of the business framework), they have the opportunity to grow in a sustainable manner and contribute to the formal economy.

Validation of this concept is required to determine whether the research hypothesis can be accepted or not. 


\section{RESEARCH DESIGN AND METHODOLOGY}

Establishing networks of small businesses, and then integrating these networks of SMMEs with formal economic activities, requires a platform through which resources, knowledge, and skills can be transferred to informal entrepreneurs. Such a platform would be realised through the establishment of a legal business entity based on the concept of the business framework.

Since this objective relates to the field of enterprise engineering, it was appropriate first to identify relevant engineering tools for characterising these informal SMMEs, as well as methods that should be followed for developing the business framework. Once the necessary engineering tools had been selected, these informal SMMEs were characterised and evaluated to determine which business processes had to be reengineered to improve overall operation and sustainability. From this business assessment, a requirements list was compiled that acted as a specification sheet for the business framework. The next phase was to develop the business framework based on the specifications in the requirements list. Lastly, the concept of the business framework was tested by means of a case study.

\section{Enterprise engineering tools and methodologies}

Three enterprise engineering methodologies were selected to perform an assessment on SMMEs operating in the informal economy. The Enterprise Life Cycle Methodology (ELCM) of Himes and Swelfer [8] was used to determine the impact of environmental elements on high level business functions like strategic planning, enterprise planning, management, and the influence of business drivers. It also provided an understanding of the level of integration between internal business activities like project execution and operations.

The Value Chain of Porter [17] was used to determine how business processes add value to the products or services provided by these SMMEs. It also assesses the level of maturity of customer and supplier interaction. The supporting activities were assessed to evaluate their effectiveness in providing a competitive advantage to the enterprises.

Finally, a GAP Analysis was used to transform these informal SMMEs from their isolated existence into a networked environment where they could operate as role players in the business framework.

\section{SMME assessment}

In collaboration with Linge Lethu Business Support ${ }^{2}$ and the Global Competitiveness Centre $^{3}$ (GCC), ten typical informal SMME businesses were interviewed. These

\footnotetext{
${ }^{2}$ Linge Lethu Business Support is a non-governmental organisation supporting start-up SMMEs.

${ }^{3}$ The GCC at the Industrial Engineering Department of the University of Stellenbosch specializes in researching tools and methodologies for enterprise engineering with the aim of improving competitiveness.
} 
business interviews covered three market areas (Figure 1). Assessments were made using the enterprise engineering tools mentioned above. The following business processes were selected as key processes for the GAP Analysis:

- Customer and Supplier Management.

- Marketing and Sales.

- Logistics.

- Operations.

- Management Responsibilities.

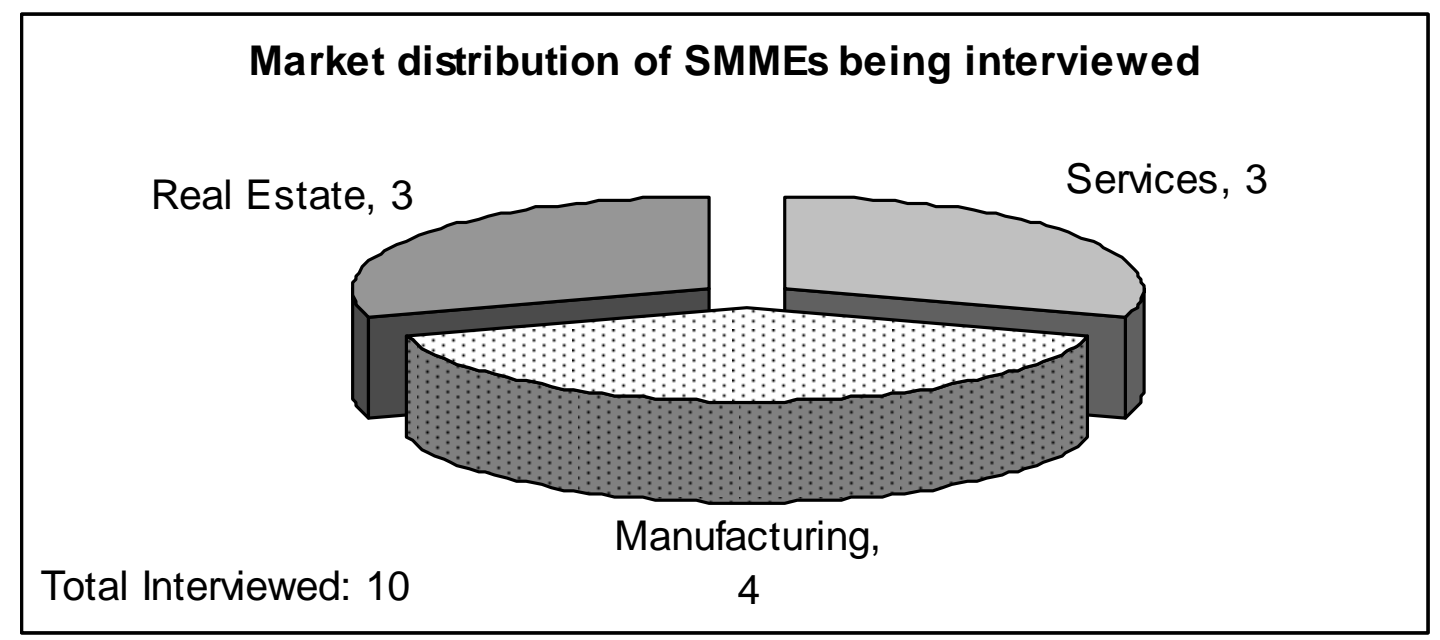

Figure 1: Market distribution of SMMEs being interviewed.

An analysis of these business processes led to a list of requirements for the business framework. The analysis was done for those SMMEs being interviewed, and findings were correlated with conditions pertaining to informal SMMEs as found in the literature. Table 1 lists these requirements.

\section{BUSINESS FRAMEWORK DEVELOPMENT}

Developing a business framework that addresses all the aspects listed in Table 1 requires collaboration between various role players (e.g. the government, companies from the formal economic sector, financial institutions, and investors), as shown in Figure 2. An important contributing factor to the success of such a venture is shared ownership of the legal businesses entity. Development of the business framework was done from a bottom-up perspective, where attention was given first to the requirements of SMMEs, then the legal business entity, and, lastly, linking the legal business entity with larger companies.

It can be seen as enterprise integration implemented at three levels:

- Integration of internal business processes for informal SMMEs

- Integration between businesses affiliated to a legal business entity, and

- Integration of such a legal business entity with larger companies. 
The business framework should provide an environment that supports similar informal SMMEs.

The business framework should help these SMMEs to build, manage, and maintain customer and supplier relationships.

The business framework should support these SMMEs in the necessary marketing and sales activities.

The business framework should provide a logistics infrastructure and support its management.

The business framework should support these SMMEs through the growing pains of starting a business. This should include business plans, strategic planning, project management, production, quality control, access to finances, and enterprise integration.

The business framework should support these SMMEs with general financial services like book keeping, financial analysis and forecasts, taxation, and cash flow management.

The business framework should provide an environment that stimulates innovative solutions to improve business processes, and adds value to products or services being sold to customers.

The business framework should be aligned with the local government's economic growth requirements in order to benefit from governmental support for these SMMEs.

The business framework should address the socio-economic problems that most informal SMME-owners and entrepreneurs face every day.

\section{Table 1. Requirements list for the business framework.}

\section{The rationale}

As determined by the assessments in the previous section, many entrepreneurs and SMMEs in the informal economy operate in relative isolation and do not have formal management procedures in place. When some of these informal businesses (operating in the same line of business) are teamed together to form a network, they could be seen as workstations in a virtual supply chain, adding value to raw materials by performing physical actions on it. As with any supply chain, the system has to cater for raw materials (which implies suppliers) and deliver final products (which implies customers). The same arguments apply to businesses in the services industry. Transportation of raw materials to, and final products from, these virtual workstations requires a logistics infrastructure.

If a business framework is designed in which a network of informal SMMEs fulfil the 'operations' activity, with a legal business entity taking responsibility for the other business activities, it results in a system that acts as a supply chain, with the 
advantages of an integrated logistics infrastructure and customer and supplier relationships. In other words, the concept of a business framework would represent a normal company, except that the physical work would be done by informal SMMEs and not by employees of the legal business entity within the business framework.

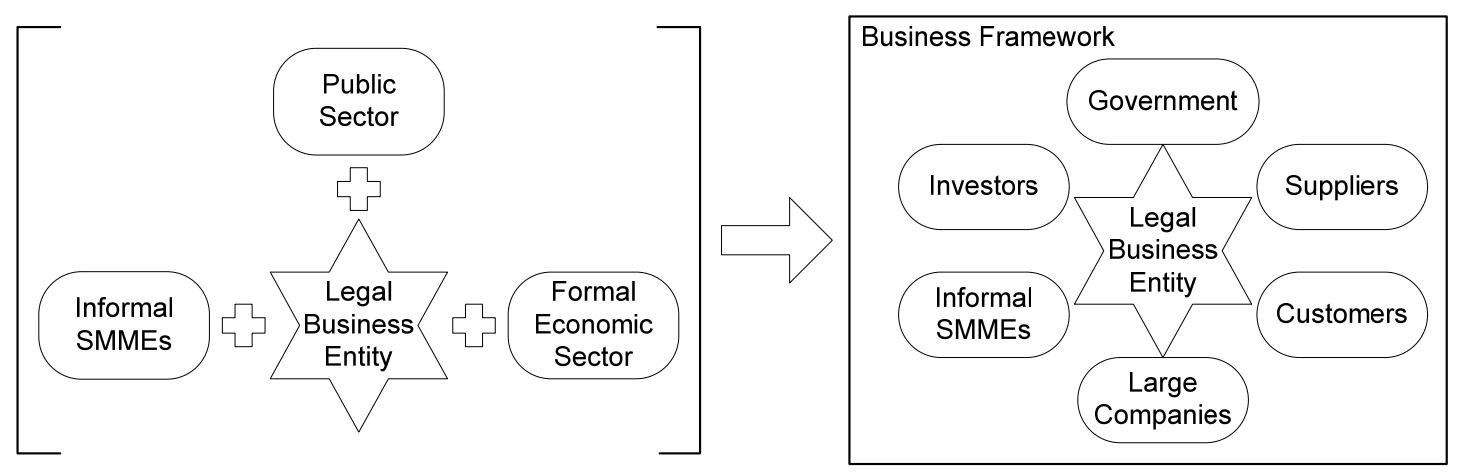

Figure 2: Development of the business framework.

\section{Enterprise architecture}

This business framework's enterprise architecture is complex, owing to the wide range of situations for which it has to cater. The main complexities are:

- The interface between SMMEs from the informal economy and larger companies from the formal economic sector.

- The range of services provided to SMMEs has to change over time. In order to allow SMMEs to mature and to start taking responsibility for their internal processes, the provision of services by the legal business entity has to change (that is, be reduced) over time. The resulting system should thus be designed to allow for changes at specific intervals. These changes will have an influence on the interfaces between the legal business entity and affiliated SMMEs.

- Human factors will add to the complexities as various people are required to manage processes within such a business framework. These people would come from different backgrounds, from very formal to informal. Complexities increase with the number of people involved, especially if they are from different backgrounds.

Developing such a composite enterprise architecture demands guidance from an enterprise reference architecture. The Zachman Framework was used as enterprise reference architecture for planning, designing, and building the business framework. A basic understanding of the Zachman Framework is given by O'Rourke et al [16] who state that the Zachman Framework for Enterprise Architecture "is a set of assumptions, concepts, values, and practices that constitutes a way of viewing reality. Zachman's Framework is organised as 36 cells arranged in a six-by-six matrix... It is a two dimensional schema, used to organise the detailed representation of the enterprise”. Zachman's Framework, as illustrated in Figure 3, is a valuable tool for 
modelling how an organisation operates, and for enhancing the level of communication in and with an organisation.

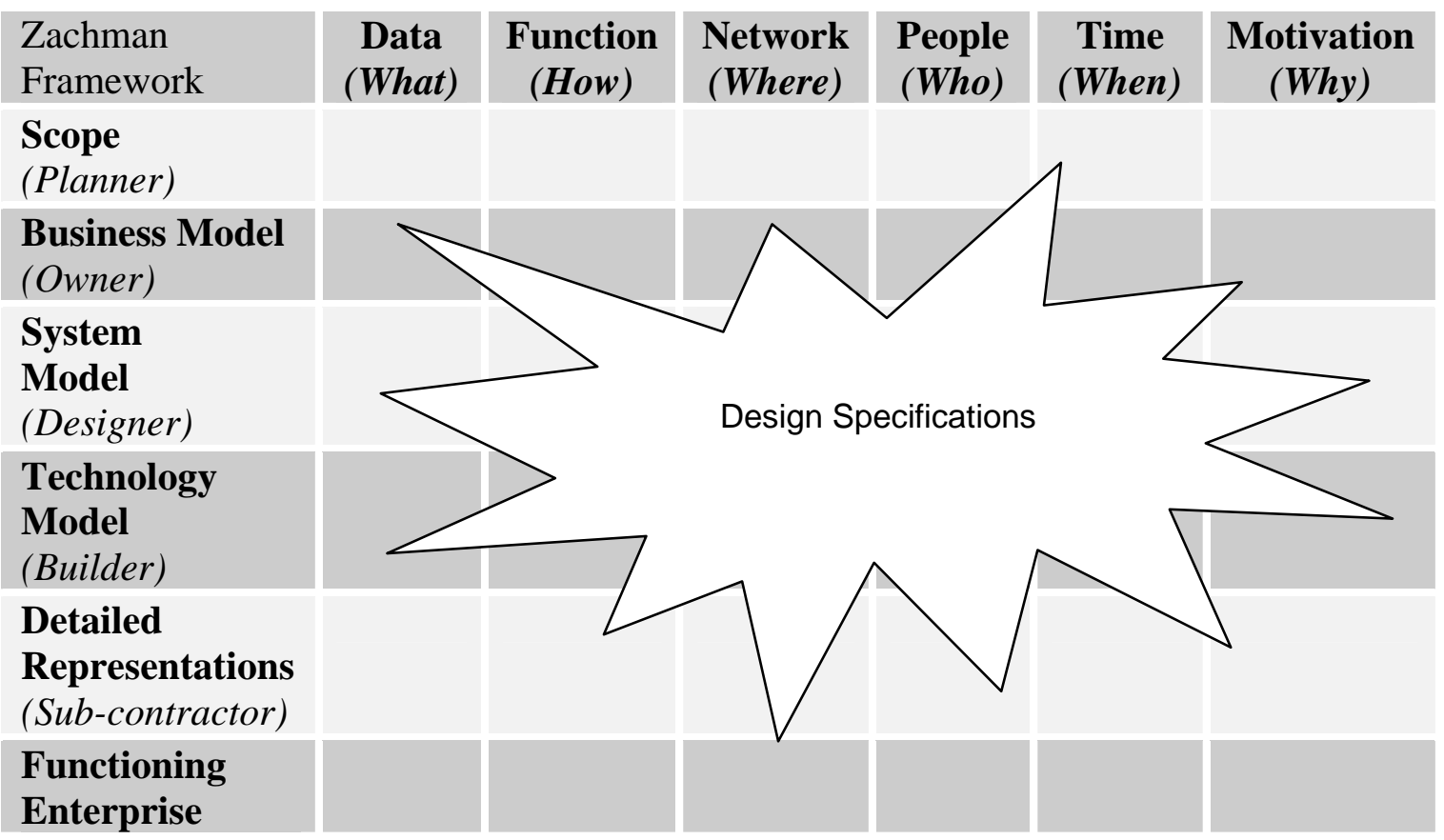

Figure 3: Outline of the Zachman Enterprise Reference Architecture.

The columns classify answers to the interrogatives: WHAT, HOW, WHERE, WHO, WHEN, and WHY. The rows classify the audience perspectives of PLANNER, OWNER, DESIGNER, BUILDER, SUB-CONTRACTOR and FUNCTIONING ENTERPRISE (Locke [14] and Zachman [21], [22]).

\section{Business framework development}

In most cases a business opportunity will be initiated from outside the realm in which informal SMMEs operate. The government, for instance, may recognise a certain business opportunity or business driver. If this opportunity proves to have a viable business case, the government then has to find business partners from the private sector. Once the partners are identified, a team representing the government and business partners have to start with a business plan and the development of the business framework. This process should address aspects like registration of a legal business entity, opening bank accounts, assigning responsibilities to the management team, selecting a board of directors, developing a business plan, etc. Once the business framework was operational, the team would then search for SMME owners who would fit into the environment of the business framework. A contract between SMME owners and the registered legal business entity of the business framework would have to be signed, after which collaboration could start.

Figure 4 is a high-level illustration of the interactions between the stakeholders. 
Partners in such a business framework need to understand that the main aim is to develop an environment for SMMEs to grow, and that there would not always be large profit margins. While the objective is obviously to make profit, the focus should remain on social returns, community development, and sustainable workcreation through self-employment. The business framework is seen as a mechanism to achieve this vision.

\section{CASE STUDY}

This case study demonstrates that the concept of a business framework can be successful and rewarding for all role players. Information and data used in this case study was provided by the Department of Aquaculture of the University of Stellenbosch. The authors, together with Linge Lethu Business Support, acted as consultants for the project, obtaining funds from international investors ${ }^{4}$. This project initiated a long-term Small Farmers Development Programme.

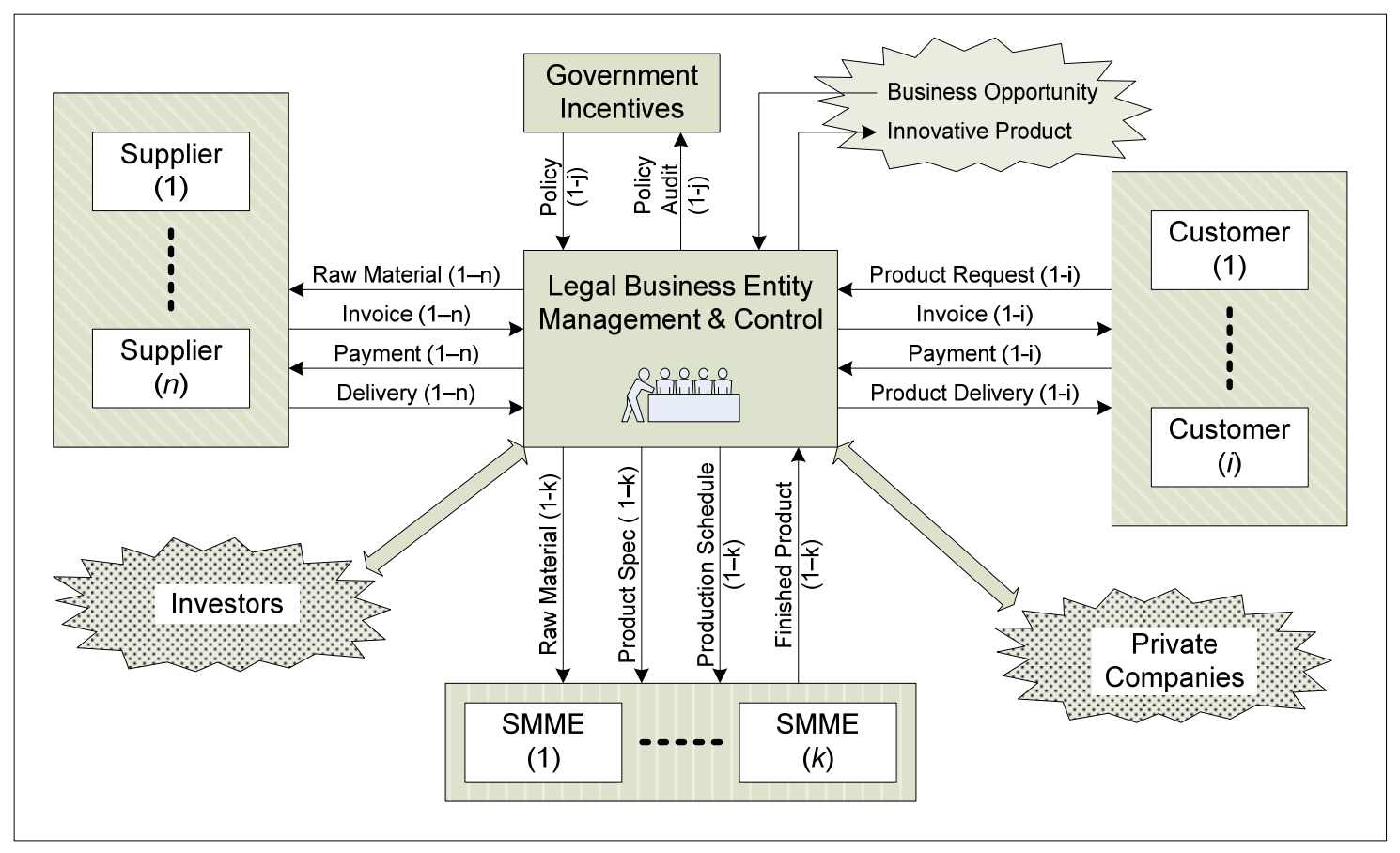

Figure 4: Physical data model of the business framework.

\section{Business opportunity}

The Department of Aquaculture of the University of Stellenbosch saw a business opportunity to supply fish to the growing demand for trout in the South African market. The shortage of trout supplies is about 200 tons per year. Furthermore, the Western Cape provides an outstanding habitat for Rainbow Trout, and is an area with many farms and irrigation dams. The question was how to exploit the Western Cape as an environment for this business opportunity. Aquaculture provides an opportunity

\footnotetext{
${ }^{4}$ Woord en Daad from the Netherlands provided funding for infrastructure lay-out of two farms.
} 
for rural communities to participate in agribusiness and regional economies without owning land, which is usually a prerequisite.

\section{Business framework}

The objective of this research project was to develop a sustainable solution that could support SMMEs through their start-up phases, and enable them to grow into sustainable businesses that actively participate in the mainstream economy. This was achieved through:

- Investigations of the reasons why many of these SMMEs struggle to survive.

- Research into current principles and policies implemented by the South African government, and their effectiveness.

- Evaluation of the business processes within these SMMEs, using engineering methodologies and tools.

- The development of a business framework according to the Zachman Enterprise Architecture Framework.

The successful application of the business framework concept in the small-scale fish farming project serves as evidence that the research hypothesis can be accepted.

\section{Hands-on Fish Farmers Co-operative}

This business structure supports participating small-scale fish farmers with purchases, marketing, loans, security, quality controls, and management tasks. The Hands-on Fish Farmers Co-operative has the following business objectives, according to co-operative practices:

- To act as a fish dealer and undertake the marketing of fish and fish products.

- To process fish and fish products.

- To buy, hire, or otherwise acquire requisites, boats, permits, or quotas necessary for use in fishing operations.

- To facilitate capacity-building, including training and extension services.

- To supply members with essential inputs, e.g. feeds and fingerlings.

- To assist members in accessing finance to run their businesses effectively and efficiently.

- To assist members with financial services and bookkeeping practices.

The operational structure with its role players is illustrated in

Figure 5.

\section{Small Scale Fish Farming}

Small-scale fish farmers each implement a floating system that consists of a platform with two polyethylene cage nets of $10 \mathrm{~m} \times 10 \mathrm{~m} \times 5 \mathrm{~m}$ each. Each unit can produce six tons of rainbow trout during the winter months, followed by the production of 1 to 1.25 tons of tilapia during the summer months. Trout are supplied under contract to 
existing processing companies for the manufacture of high-value products, while tilapia is sold as an affordable food source within local communities.

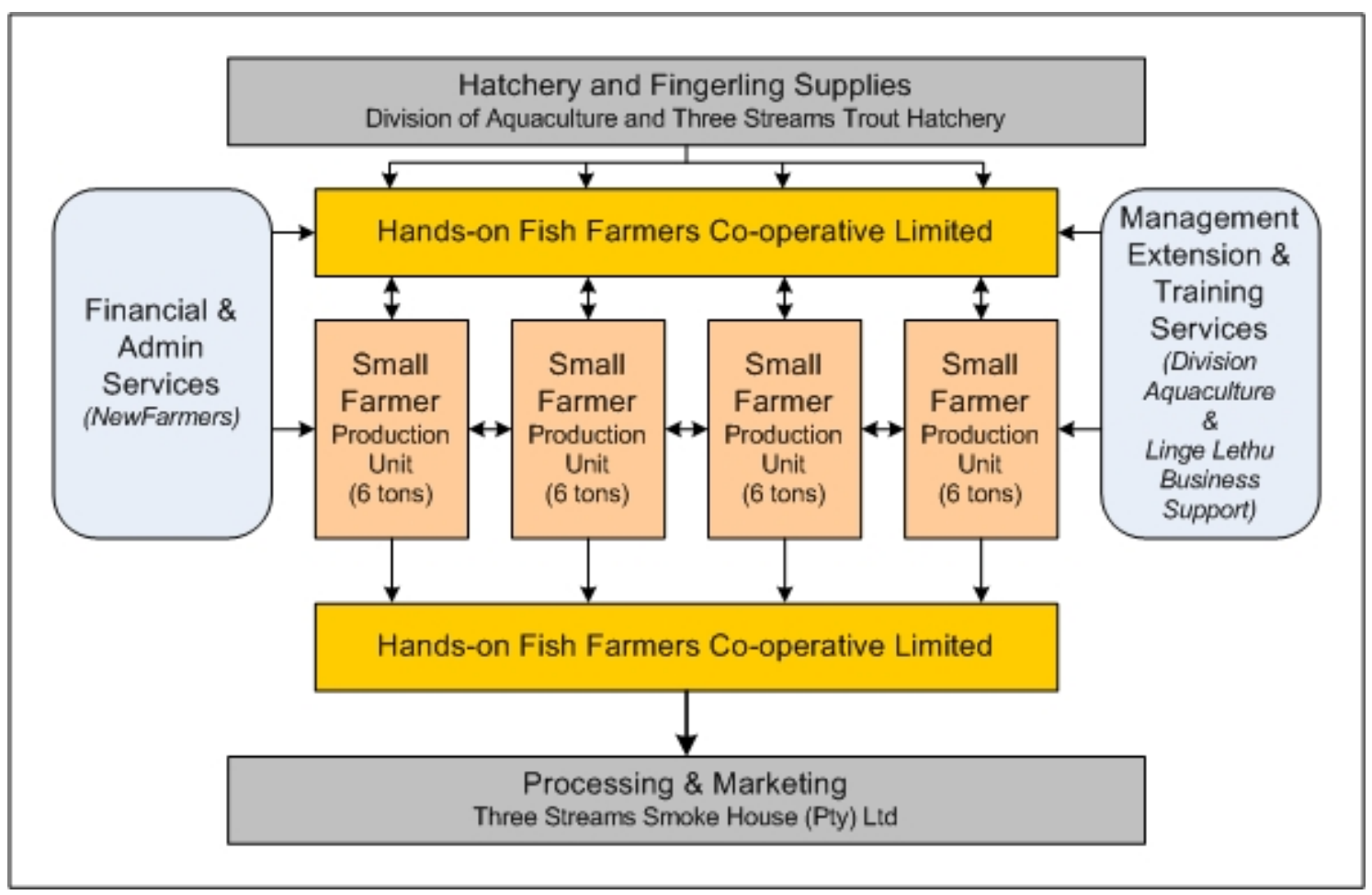

Figure 5: Operational structure of small-scale fish farming project.

Fingerlings are bought at the beginning of each season and stocked in the floating cage systems. Fish farmers feed and take care of the fish during the production cycle. An extension officer from the co-operative visits the farmers on a monthly basis, during which performance and managerial systems are evaluated.

\section{Project conclusion}

The annual net profit of the small-scale farming units is up to three times the average annual wages of farm labourers in these rural areas (Oberholster [15]). The Small Farmers Development Programme has proven its ability to make a meaningful contribution to the income and nutritional status of these communities, while also providing a means for the development of human resources. The programme has the potential to create a substantial number of employment opportunities. Implementation of 30 farms over a three-year period will lead to 64 direct and 33 indirect employment opportunities. Fourteen farms are already in operation.

The Small Farmers Development Programme saw excellent co-operation from all role players in laying down a business framework for infrastructure, facilities, training, and extension services provision. The programme has developed a broad network between national and international institutions, allowing knowledge transfer through bilateral programmes. 


\section{RESULTS AND DISCUSSION}

From a business framework development perspective, the small-scale fish farming project fits the role of case study perfectly: it demonstrates the importance of a 'controlling company' that acts on behalf of the associated businesses. Emphasis is placed on the lack of skills of these prospective business owners: although they can perform physical operations, they need training in the fields of business skills, managerial skills, system design, production planning, financial analysis, etc.

The objective of this research project was to develop a sustainable solution that could support SMMEs through their start-up phases, and enable them to grow into sustainable businesses that actively participate in the mainstream economy. This was achieved through:

- Investigations of the reasons why many of these SMMEs struggle to survive.

- Research into current principles and policies implemented by the South African government, and their effectiveness.

- Evaluation of the business processes within these SMMEs, using engineering methodologies and tools.

- The development of a business framework according to the Zachman Enterprise Architecture Framework.

The successful application of the business framework concept in the small-scale fish farming project serves as evidence that the research hypothesis can be accepted.

\section{REFERENCES}

[1] Balkenhol, B. and Evans-Clock, C. 2003. 'Private equity and capitalisation of SMMEs in South Africa: Quo Vadis?’ Social Finance Programme \& InFocus Programme on Boosting Employment through Small Enterprise Development, Working Paper No. 34, Ebony Consulting International (Pty) Ltd.

[2] Baum, J.R., Locke, E.A. and Smith, K.G. 2001. 'A multidimensional model of venture growth', Academy of Management Journal, Vol 44, No 2, pp292303.

[3] Berry, A., Blottnitz, M., Cassim, R., Kesper, A., Rajaratnam, B. and Seventer, D.E., 2002. The Economics of SMMEs in South Africa, Trade and Industrial Policy Strategies.

[4] Budlender, D., Skinner, C. and Valodia, I. 2004. 'Budgets and the informal economy: An analysis of the impact of the budget on informal workers in South Africa', School of Development Studies, University of KZN, South Africa.

[5] Burger, D. 2004. 'Government Communication and Information System', The South African Yearbook 2003/2004.

[6] Devey, R., Skinner, C. and Valodia, I. 2006. 'Second best? Trends and linkages in the informal economy in South Africa', Development Policy 
Research Unit, Working Paper 06/102, Human Science Research Council Press, Cape Town.

[7] Drennan, J., Kennedy, J. and Renfrow, P. 2005. 'Impact of childhood experiences on the development of entrepreneurial intentions', Entrepreneurship and Innovation, pp 231-238.

[8] Eapen, M. 2001. 'Woman in informal sector in Kerala: Need for reexamination', Economic and Political Weekly, June 30.

[9] Himes, G. and Swelfer, M. 2003. 'Building an Enterprise Life Cycle', MITRE Publications.

[10] International Labour Organisation. 2002. 'Woman and men in the informal economy, a statistical picture', International Labour Organisation, Geneva.

[11] Lehohla, P. 2002. Statistics South Africa: The contribution of small and micro enterprises to the economy of the country: A survey of non-VAT-registered business in South Africa: Part 1 - Summary and Tables, Stats SA Library, Pretoria, South Africa, November 2002.

[12] Lehohla, P. 2002. Statistics South Africa: The contribution of small and micro enterprises to the economy of the country: A survey of non-VAT-registered business in South Africa: Part 2 - Narrative Report, Stats SA Library, Pretoria, South Africa, November 2002.

[13] Le Roux, M. 2006. 'South Africa: Mpahlwa offers help to small businesses off beaten track', Business Day, Johannesburg, June 27.

[14] Locke, S. 2003. 'The Zachman Enterprise Architecture', Metadata Systems Software Inc., Mississauga, Toronto, Canada.

[15] Oberholster, J. 2001. An investigation into the long-term sustainability of small aquaculture systems in the Western Cape of South Africa, Division of Aquaculture of Stellenbosch University, p88.

[16] O'Rourke, C., Fishman, N. and Selkow, W. 2003. 'Enterprise Architecture using the Zachman Framework', Thomson Course Technology, Boston, USA.

[17] Porter, M.E. 1985. 'Competitive advantage, creating and sustaining superior performance', Free Press, 1985.

[18] Rogerson, C. 2004 'The impact of the South African Government's SMME programmes: A ten year review (1994-2003)`, Development Southern Africa, Vol. 21 (5).

[19] Rotefoss, B. and Kolvereid, L. 2005. 'Aspiring, nascent and fledging entrepreneurs: An investigation to the business startup process', Entrepreneurship and Regional Development, Vol 17, No 2, pp109-127.

[20] South Africa. 1996. National Small Business Act. No 92 of 1996. Pretoria: The President's Office, No 1901. November, 27. [Laws]

[21] Zachman, J.A. 1997. Concepts of the framework for enterprise architecture, background, description and utility, Zachman International, Inc., Information Engineering Services (Pty) Ltd.

[22] Zachman, J.A. 2000. 'Framework for enterprise architecture', Enterprise Physics 101 Seminar, Zachman International, Inc., 2222 Foothill Blvd, Suite 337, La Canada, Ca. 